\title{
Incorporating pest management into the design of multiple goal-oriented cropping systems
}

\author{
Dan O. Chellemi
}

Received: 30 September 2008 / Accepted: 11 November 2008 / Published online: 8 January 2009

(C) The Author(s) 2008. This article is published with open access at Springerlink.com

\section{Biography}



Dan O. Chellemi born in the USA in 1959. Research Plant Pathologist, U.S. Department of Agriculture, Agricultural Research Service (USDA, ARS). 1982, B.S. Plant Science, U. of Florida; 1986, M.S. Plant Pathology, U. of Hawaii-Manoa; 1990, Ph.D., Plant Pathology, U. of California-Davis. 1990 Post-Doctoral Researcher, U.S. Forest Service, Coweeta, North

D. O. Chellemi $(\bowtie)$

U. S. Department of Agriculture, Agricultural Research Service, U. S. Horticultural Research Laboratory, 2001 South Rock Road,

Fort Pierce, FL 34945, USA

e-mail: dan.chellemi@ars.usda.gov
Carolina; 1991-96 Assistant Prof., and 1996-97 Associate Prof., U. of Florida, Plant Pathology Department, North Florida Research \& Education Center, Quincy, FL, USA; 1997-present, Lead Scientist, USDA, ARS research project 'Alternatives to methyl bromide soil fumigation for vegetable and floriculture production'; 2007-present, Project Coordinator, USDA, ARS AreaWide Pest Management Project for Methyl Bromide Alternatives. Publications: Over 50 published papers in peer-reviewed journals, four peer-reviewed book chapters. Research: Current research involves the development and implementation of pest management systems designed to minimize environmental disruption and reduce chemical inputs while remaining technically feasible and economically viable. Research accomplishments include the evaluation of bacterial wilt-resistant tomato genotypes using a regional approach, the adaptation of soil solarization to the integrated management of soilborne pests of tomato under humid conditions, development of an alternative, low-input production system for fresh market tomatoes, and the characterization of land and crop management effects on the stability of soil fungal and bacterial communities.




Cover crops are temporary or seasonal vegetative covers grown to protect and improve soil quality, conserve water, enhance pest suppression and promote biological diversity. Despite their numerous benefits, many agricultural sectors have been reluctant to integrate them into crop production systems. In a survey of 3,500 midwestern U. S. farmers, only $18 \%$ of respondents reported using cover crops, even though most believed that doing so would increase soil organic matter and reduce erosion (Singer et al. 2007). In a survey of central California tomato and safflower farmers, only $28 \%$ acknowledged planting cover crops despite an understanding of their benefits to soil quality (Ridgely and Van Horn 1995). Similarly, Florida vegetable farmers dependent upon methyl bromide soil fumigation have been reluctant to plant pestsuppressive cover crops despite knowledge of their beneficial effects (personal observation). For most farmers, the agronomic and pest management benefits of cover crops do not outweigh the cost and time required to plant and manage them. Improved soil fertility and pest suppression can be achieved using less expensive but easier to manage inputs such as fertilizer and pesticides. Failure to achieve widespread acceptance is due in part to differences in the goals of the cover crops (and the research programs that develop them) and the farmers who plant them. In most cases the cover crops were selected, evaluated and promoted to achieve the goals of improving soil fertility or pest suppression. However, for many farmers their principal goal is to maintain or increase the profitability of their crop production systems.

Integrating multiple economic, environmental, and social goals into the design of agricultural crop production systems is a key feature of an ecological or total systems approach to pest management (Levins 1986; Lewis et al. 1997). These approaches to pest management operate under the premise that biological and microbiological communities indigenous to agroecosystems can function to limit pest outbreaks through self-regulating, ecological feedback mechanisms. For example, the general and specific suppression of soilborne plant diseases via substrate or host plant mediated stimulation of native microbial communities (Cotxarrera et al. 2002; Mazzola 2004; McSpadden-Gardener 2007; Rotenberg et al. 2007; Van Os and van Ginkel 2001). These naturally occurring mechanisms are promoted through the judicious use of locally available resources and land management practices. Ecological or total systems approaches to pest management are also compatible with organic and sustainable approaches to crop production. Unfortunately, as in the case of cover crops, farmers are often reluctant to invest the extra time and money needed to establish beneficial biological communities through additional crop management practices.

Can sustainable pest management be achieved through self regulating feedback mechanisms? An example taken from a wet-rice farming region on the Indonesian island of Bali provides evidence that it is achievable, albeit even if arrived at serendipitously. In this 97,337 hectare region, farmers must synchronize their planting and irrigation schedules by subregion to ensure the adequate availability of water resources (Lansing et al. 1998). The synchronized planting schedules also function to suppress the growth and dispersal of rice pests including rats, insects and insect-vectored plant diseases (Aryawan et al. 1993). Over time, the mutually compatible goals of crop production and pest management facilitated the functional system dependent selection and ecological feedback regulation of pest outbreaks within the region (Lansing et al. 1998).

To facilitate incorporation of pest management goals into the design of crop production systems, several suggestions are offered. Inclusion of farmers, production specialists and researchers from disciplines unrelated to pest management at the initiation of research programs is necessary to ensure a mutual understanding of each participant's concerns. From this starting point multiple goals that are mutually compatible can be incorporated into the research and development of cropping systems. In turn, funding agencies and grant review panels should recognize the advantages of this approach to building multidisciplinary projects and reward such efforts.

Support for long-term, high risk ecosystems-based research should be encouraged as pest populations are often regulated by complex interactions involving environmental and edaphic factors, biological and microbial communities, and plant hosts. A further understanding of ecological theories such as diversity/ stability relationships coupled with continued scientific efforts to link microbial community structure to ecosystem function and crop management practices is needed to develop and promote the desired biological balance in agroecosystems. 
Cover crops and their lack of adoption provide an interesting case study for the integration of pest management goals into commercial cropping systems. The surveys mentioned previously established that costs and time required to plant and manage cover crops limit their application. To offset those input costs, the generation of a direct source of income from their cultivation (i.e., an economic goal) should be added to improved soil fertility and pest management (i.e., environmental goals) as the cover crops are selected and evaluated. Newly emerging issues that will impact the long-term success of crop production enterprises should also be addressed when selecting and evaluating cover crops. For example, the increased energy demands and environmental regulations being imposed upon farming operations. Consideration of a cover crop's ability to sequester carbon and provide a source of biofuel feedstock that does not compete directly with food production can address those emerging issues when added to the selection and evaluation criteria. This approach of using cover crops to achieve multiple goals is one way to incorporate pest management into the design of multiple goal-oriented cropping systems.

Open Access This article is distributed under the terms of the Creative Commons Attribution Noncommercial License which permits any noncommercial use, distribution, and reproduction in any medium, provided the original author(s) and source are credited.

\section{References}

Aryawan, I. G. N., Widarta, I. N., Suzuke, Y., \& Nakasuji, F. (1993). Life table analysis of the green rice leafhopper, Nephotettix virescens (Distant), an efficient vector of the rice tungro disease in asynchronous rice fields in Indonesia. Researches on Population Ecology, 35, 31-43.

Cotxarrera, L., Trillas-Gay, M. I., Steinberg, C., \& Alabouvette, C. (2002). Use of sewage sludge compost and Trichoderma asperellum isolates to suppress Fusarium wilt of tomato. Soil Biology \& Biochemistry, 34, 467-476.

Lansing, J. S., Kremer, J., \& Smuts, B. B. (1998). Systemdependent selection, ecological feedback and the emergence of functional structure in ecosystems. Journal of Theoretical Biology, 192, 377-391.

Levins, R. (1986). Perspectives in integrated pest management: from an industrial to an ecological model of pest management. In M. Kogan (Ed.), Ecological theory and integrated pest management (pp. 1-18). New York, NY: Wiley.

Lewis, W. J., van Lenteren, J. C., Phatak, S. C., \& Tumlinson III., J. H. (1997). A total system approach to sustainable pest management. Proceedings of the National Academy of Sciences of the United States of America, 94, 1224312248.

Mazzola, M. (2004). Assessment and management of soil microbial community structure for disease suppression. Annual Review of Phytopathology, 42, 35-59.

McSpadden-Gardener, B. B. (2007). Diversity and ecology of biocontrol Pseudomonas spp. in agricultural soils. Phytopathology, 97, 221-226.

Ridgely, A. M., \& Van Horn, M. (1995). Survey of annual crop growers regarding cover crops. University of California, Sustainable Agriculture Research and Education Program, 7(3), 1-3.

Rotenberg, D., Joshi, R., Benitez, M. S., Chapin, L. G., Camp, A., Zumpeta, C., et al. (2007). Farm management effects on rhizosphere colonization by native populations of 2,4diacetylphloroglucinol-producing Pseudomonas spp. and their contributions to crop health. Phytopathology, 97, 756-766.

Singer, J. W., Nusser, S. M., \& Alf, C. J. (2007). Are cover crops being used in the US Corn Belt? Journal of Soil and Water Conservation, 62, 353-358.

Van Os, G. J., \& van Ginkel, J. H. (2001). Suppression of Pythium root rot in bulbous iris in relation to biomass and activity of the soil microflora. Soil Biology \& Biochemistry, $33,1447-1454$. 